\title{
ANALISIS PENGINDERAAN JAUH DAN PEMODELAN 3D FAULT FRACTURE DENSITY (FFD) DALAM PENENTUAN ZONA PERMEABILITAS PERMUKAAN DI WILAYAH PANAS BUMI GUNUNG TAMPOMAS, JAWA BARAT
}

\section{REMOTE SENSING ANALYSIS AND 3D FAULT FRACTURE DENSITY (FFD) MODELING INTO DETERMINATION OF SURFACE PERMEABILITY ZONES IN MOUNT TAMPOMAS GEOTHERMAL AREA, WEST JAVA}

\author{
Abizar Adi, Agus Didit Haryanto, Johanes Hutabarat, dan Dewi Gentana \\ Fakultas Teknik Geologi, Universitas Padjadjaran \\ abizar861@gmail.com
}

\section{ABSTRAK}

Wilayah Gunung Tampomas yang terletak di Kecamatan Buahdua, Kecamatan Conggeang, dan Kecamatan Tanjungkerta, Kabupaten Sumedang, Jawa Barat dipilih sebagai daerah penelitian karena diperkirakan memiliki potensi panas bumi dengan hadirnya manifestasi panas bumi berupa mata air panas di sekitarnya. Kemunculan manifestasi berhubungan dengan zona permeabilitas yang dikontrol oleh struktur geologi. Kelurusan punggungan dan lembah diamati dan dianalisis menggunakan citra penginderaan jauh ASTER GDEM dan peta Rupa Bumi Indonesia (RBI), skala 1:25.000. Tujuan penelitian untuk mengetahui hubungan antara permeabilitas dengan kemunculan manifestasi panas bumi di daerah penelitian. Metode penelitian dengan melakukan analisis penginderaan jauh dan Fault Fracture Density (FFD) menggunakan pemodelan 3D micromine software. Hasil analisis penginderaan jauh dengan azimut penyinaran dari $0^{\circ}, 45^{\circ}, 90^{\circ}, 135^{\circ}$ dan altitude $45^{\circ}$ memperlihatkan pola utama kelurusan punggungan-lembah yang diinterpretasikan sebagai patahan memiliki arah relatif barat laut-tenggara dan timur laut-barat daya. Indikasi struktur geologi di lapangan diperlihatkan oleh morfologi bentuk punggungan lembah, di beberapa tempat memiliki tebing curam membentuk gawir sesar dan faset segitiga. Hasil analisis FFD di daerah penelitian memiliki tingkat permeabilitas yang bervariasi dengan nilai FFD rendah $\left(0,00-3,00 \mathrm{~km}^{-1}\right)$, sedang $\left(3,00-6,00 \mathrm{~km}^{-1}\right)$ dan tinggi $\left(6,00-9,33 \mathrm{~km}^{-1}\right)$. Manifestasi panas bumi muncul pada zona permeabilitas yang memiliki nilai FFD sedang hingga tinggi yang ditandai oleh warna jingga dan merah. Dari pemodelan 3D micromine software terhadap zona permeabilitas dan ploting mata air panas di permukaan terlihat secara jelas kemunculan mata air panas ke permukaan difasilitasi oleh patahan yang berkembang di daerah penelitian.

Kata Kunci: ASTER GDEM, Fault Fracture Density, Manifestasi Panas Bumi, Permeabilitas

\section{ABSTRACT}

The area of Mount Tampomas which is located in Buahdua District, Conggeang District, and Tanjungkerta District, Sumedang Regency, West Java was chosen as the research area because it is predicted to have geothermal potential with the presence of geothermal manifestations such as hot springs. The presence of manifestations relates to permeable zones controlled by geological structures. The lineament of the ridge and valley was observed and analyzed using ASTER GDEM remote sensing imagery and Indonesia Earth Form map (RBI), scale 1:25.000. The purpose of the study is to find out the relationship between permeability and the presence of geothermal manifestations in the research area. Research method by conducting remote sensing and fault fracture Density (FFD) analysis using $3 D$ micromine software modeling. Results of remote sensing analysis with irradiation angle of $0^{\circ}, 45^{\circ}, 90^{\circ}, 135^{\circ}$ and altitude $45^{\circ}$ shows the main pattern of the ridge - valley lineament interpreted as a fault in the research area have a relatively northwest-southeast 
and northeast-southwest direction. Indications of geological structures in the field are shown by the morphology of valley-ridges, in some places has a steep slope that form the fault escarpment and triangular facet. The FFD analysis results in the research area have varying permeability classes shown by low FFD values $\left(0.00-3.00 \mathrm{~km}^{-1}\right)$, medium $\left(3.00-6.00 \mathrm{~km}^{-1}\right)$ and high (6.00-9.33 $\left.\mathrm{km}^{-1}\right)$. The geothermal manifestations appear in the permeability zone that have medium to high FFD values marked by orange and red colors. From 3D micromine software modeling of the permeability zone and plotting of hot springs on the surface, it is clear that the appearance of hot springs to the surface is facilitated by faults that develop in the research area.

Keywords: ASTER GDEM, Fault Fracture Density, Geothermal Manifestations, Permeability

\section{PENDAHULUAN}

Indonesia memiliki potensi sumber daya panas bumi terbesar kedua dunia setelah Amerika Serikat sekitar 23.765,5 MW dengan kapasitas terpasang 2.130,7 MWe atau sekitar $8,9 \%$ dari total potensi sumber daya (Ditjen EBTKE, 2020). Salah satu daerah di Indonesia yang memiliki potensi panas bumi, dan dapat dikembangkan dan dimanfaatkan adalah di daerah Gunung Tampomas.

Syarat utama pembentuk sistem panas bumi adalah sumber panas, batuan reservoar yang harus memiliki permeabilitas yang tinggi dibentuk oleh struktur geologi dan karateristik stratigrafi, dan lapisan penudung (Kasbani, 2009). Struktur geologi (patahan/rekahan) membentuk zona permeabel memfasilitasi fluida panas bumi dari suatu kedalaman di bawah permukaan (reservoar) bermigrasi menuju ke kedalaman yang lebih rendah (Suryantini dan Wibowo, 2010).

Metode yang digunakan dalam penelitian ini yaitu analisis penginderaan jauh dan FFD yang diaplikasikan dengan pemodelan $3 D$ serta pengamatan lapangan untuk menentukan zona permeabel dan hubungannya terhadap sebaran manifestasi panas bumi di daerah penelitian. Metode ini menjadi penting dalam penelitian pendahuluan untuk mengetahui gambaran umum mengenai hubungan struktur geologi dan sebaran manifestasi sebelum dilakukan penelitian lapangan (Sasilani dan Haryanto et al., 2019).
Metode FFD adalah metode yang sederhana namun telah terbukti untuk menentukan zona permeabel sebagai indikator reservoar panas bumi. Hal ini dibuktikan oleh hasil penelitian pada lapangan panas bumi Tanggamus (Gentana dan Sukiyah et al., 2017), Candi Umbul-Telomoyo (Hermawan dan Rezky, 2011), dan Gunung Lawu (Siagian dan Maryudi et al., 2018) yang menunjukkan area dengan nilai FFD tinggi sesuai dengan area resistivitas nilai rendah menggambarkan batuan yang didemagnetisasi hidrotermal, sehingga dapat menjadi indikator reservoir panas bumi.

Secara administratif Gunung Tampomas dan sekitarnya terletak pada lima wilayah kecamatan, yaitu; Kecamatan Buahdua, Kecamatan Conggeang, Kecamatan Tanjungkerta, Kecamatan Paseh dan Kecamatan Cimalaka Kabupaten Sumedang, Jawa Barat. Secara geografis daerah penelitian terletak pada koordinat antara $6^{\circ} 40^{\prime} 31^{\prime \prime}-6^{\circ} 49^{\prime} 42^{\prime \prime}$ LS dan $107^{\circ}$ 53' 27" - $108^{\circ}$ 2' 9" BT (Gambar 1).

\section{METODOLOGI}

Objek yang diamati dalam penelitian ini adalah sifat fisik manifestasi panas bumi di daerah penelitian dan citra ASTER GDEM untuk menentukan orientasi pola kelurusan melalui interpretasi penginderaan jauh (remote sensing) dan menghitung zona permeabilitas batuan menggunakan metode Fault Fracture Density (FFD) yaitu dengan cara menarik seluruh kelurusan punggungan-lembah menggunakan aplikasi ArcMap. 


\section{MAKALAH ILMIAH}

Penarikan kelurusan dari punggunganlembah dengan alasan karena fault dan fracture yang banyak terdapat pada lembah diasumsikan sebagai zona lemah yang menjadi jalur pergerakan dari fluida panas bumi, sehingga dapat menjadi petunjuk lokasi zona permeabel (Suryantini dan Wibowo, 2010). Tahapan penelitian yang dilakukan dijelaskan sebagai berikut (Gambar 2):

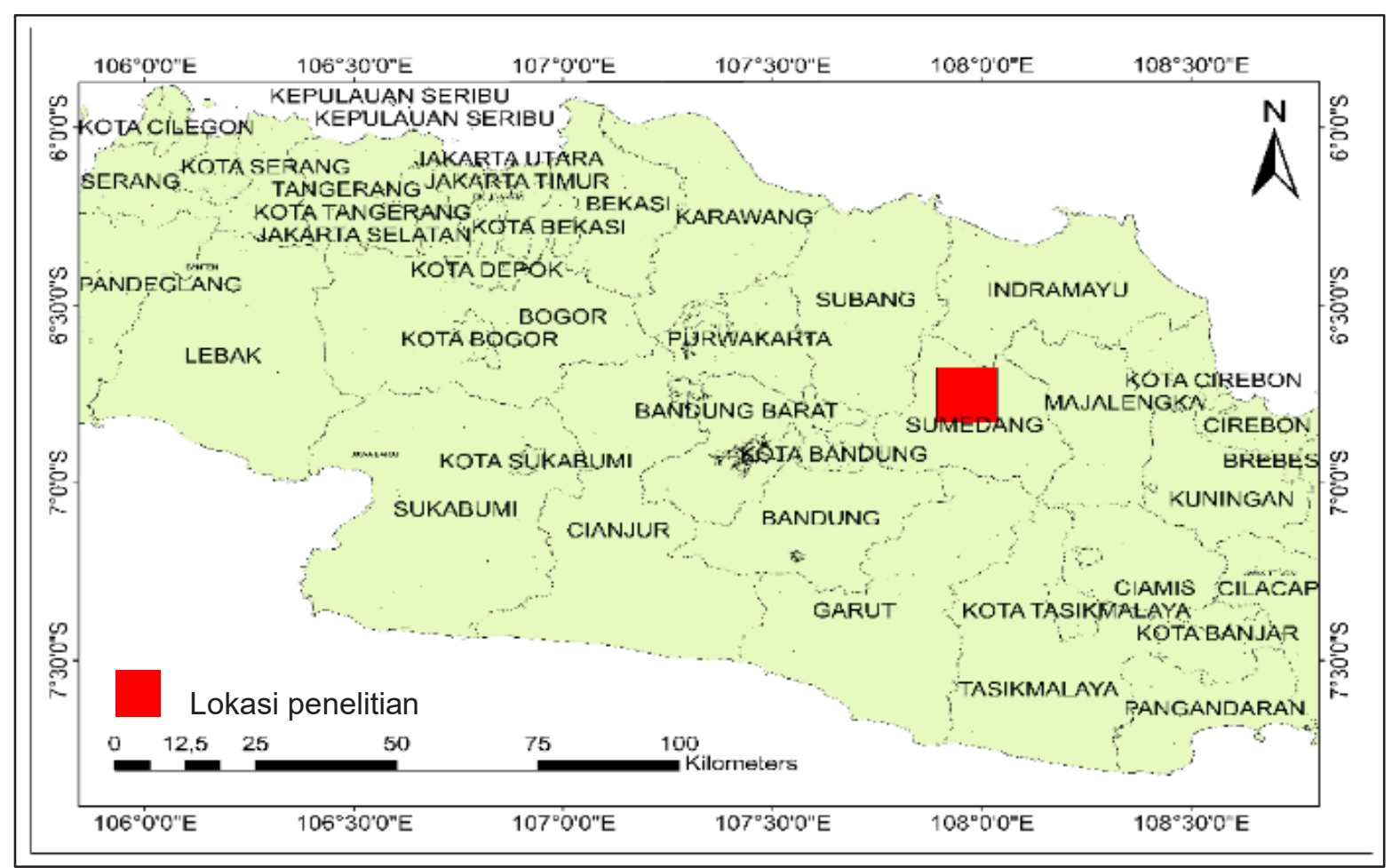

Gambar 1. Lokasi penelitian (Sumber: Indonesia Geospatial Portal)

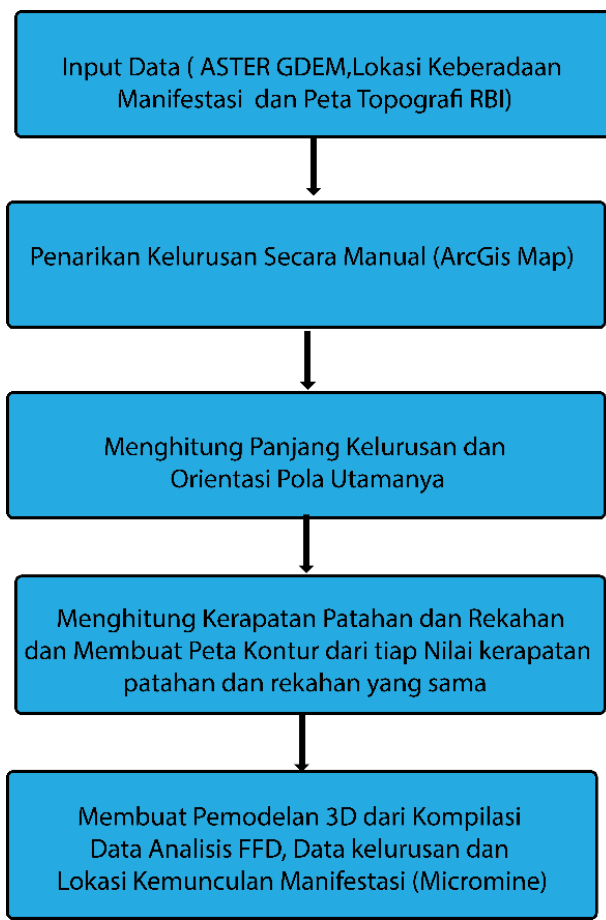

Gambar 2. Bagan menampilkan alur penelitian 


\section{Analisis Penginderaan Jauh (Remote Sensing)}

Metoda penyinaran semu dengan sudut ketinggian sumber cahaya mulai dari $0^{\circ}$, $45^{\circ}, 90^{\circ}$, dan $135^{\circ}$ dengan penyinaran konstan $45^{\circ}$ digunakan untuk menyinari relief yang dibentuk dari data ASTER GDEM, akan memperlihatkan topografi yang relatif menunjukkan kelurusan. Data topografi RBI diperoleh dari portal geospasial Indonesia dengan cara mengunduh peta per wilayah Jawa Barat, dan data ASTER GDEM diperoleh melalui aplikasi Global Mapper 20 dengan cara menghubungkan sumber data online dan memilih sumbernya ASTER GDEM. Data yang didapatkan berupa peta DEM dan topografi Kabupaten Sumedang yang dipusatkan pada pada objek lokasi penelitian yaitu Gunung Tampomas. Kemudian dilakukan penarikan kelurusan secara visual pada aplikasi ArcGIS dengan tools polyline berupa data shapefile. Kelurusan-kelurusan (punggungan-lembah) dari hasil analisis penginderaan jauh kemudian diplot ke dalam diagram roset. Hasil plot pada diagram roset akan menunjukkan arah tegasan struktur geologi (patahan) di daerah penelitian.

\section{Analisis FFD}

Menurut Thanoun (2013) metode FFD adalah suatu metode sederhana yang didasarkan pada perhitungan pola kerapatan garis kelurusan pada foto udara, sehingga dapat diketahui zonazona lemah (zona permeabel) yang dibentuk oleh sesar dan rekahan saling berhubungan. Struktur geologi seperti patahan dan rekahan mempunyai ciri khas yang dapat diamati di permukaan, yaitu berupa kelurusan (Massinai, 2015).

Tingkat permeabilitas pada batuan dapat diperoleh melalui analisis indeks geomorfik kuantitatif antar lain; kerapatan pengaliran sungai (drainage density/ $\mathrm{D}_{\mathrm{d}}$ ) bernilai rendah hingga tinggi ditunjukkan dengan nilai; 1,73-4,58 km-1 (Gentana, 2018; klasifikasi Sukiyah, 2003), dan kerapatan kelurusan geologi (lineament density $/ L_{d}$ ) bernilai rendah hingga tinggi ditunjukkan dengan nilai; $1,00-3,00 \mathrm{~km}^{-1}$ (Gentana, 2018; klasifikasi Soengkono, 1999).

Kerapatan dari patahan dan rekahan didefinisikan sebagai total panjang sebenarnya dari kelurusan yang telah ditarik dibagi dengan luas dari grid yang telah dibuat berukuran $1 \mathrm{~km} \times 1 \mathrm{~km}$. Nilai kerapatan pada setiap grid kemudian dibuat kontur yang menunjukkan nilai kerapatan yang sama. Hasilnya berupa peta kontur Fault Fracture Density (FFD) yang memberikan gambaran umum wilayah yang memiliki kerapatan patahan dan rekahan dengan nilai tertinggi mengindikasikan zona lemah/zona rekahan yang berasosiasi dengan kemunculan manifestasi panas bumi di permukaan dari fluida panas bumi dari bawah permukaan (reservoar).

\section{Pemodelan 3D}

Pemodelan 3D dilakukan untuk menggambarkan hubungan tingkat permeabilitas secara tiga dimensi berdasarkan hasil perhitungan FFD yang dikorelasikan dengan kelurusan-kelurusan hasil interpretasi penginderaan jauh dari citra satelit ASTER GDEM terhadap kemunculan manifestasi panas bumi di permukaan.

Data hasil analisis FFD, interpretasi kelurusan, lokasi kemunculan manifestasi dan data kontur topografi RBI kemudian diolah dengan menggunakaan fitur digital terrain model (DTM) pada aplikasi Micromine sehingga menghasilkan model topografi 3D dengan korelasi kelurusan (patahan), data FFD dan kemunculan manifestasi di permukaan.

\section{GEOLOGI}

\section{Stratigrafi Regional}

Berdasarkan peta geologi regional Lembar Bandung, Jawa Barat, skala 1:100.000 (P.H. Silitonga, 1973), tipe batuan di daerah Gunung Tampomas dikelompokkan dalam 6 satuan batuan (Gambar 3), dengan urutan stratigrafi dari 
yang berumur tua ke muda sebagai berikut:

a. Formasi Subang; Formasi Subang terdiri dari dua subdivisi: yaitu anggota batulempung (Msc) dan anggota batupasir (Mss) yang saling membaji dan berumur Miosen, tersebar tidak luas di tengah peta bagian utara.

b. Formasi Kaliwangu (Pk); Formasi Kaliwangu terdiri dari batupasir tufaan, konglomerat dan, jarang terdapat batugamping dan batulempung dan berumur Miosen - Pliosen.

c. Formasi Citalang (Pt); Formasi Citalang yang berumur Pliosen, terdiri dari batunapal tufaan diselingi oleh batupasir tufaan, breksi dan konglomerat.

d. Hasil Gunung Api lebih tua (Qob); Terdiri atas breksi, lahar, dan pasir tufa berlapis - lapis dengan kemiringan yang kecil berumur Plistosen.

e. Hasil Gunung Api muda; produk vulkanik berupa tuf batuapung (Qyt) dan breksi dan aglomerat (Qyb), lapili, lava, berumur Kuarter tersebar mengelilingi Gunung Tampomas dari sisi barat laut-barat-barat dayaselatan- tenggara.

f. Hasil Gunung Api muda tak teruraikan (Qyl); pasir tufaan, lapili, breksi, aglomerat dan aliran lava muda bersifat basaltik yang berumur Kuarter. Intrusi (terobosan) lava andesit (A) diendapkan di sungai berumur Holosen juga tersebar di bagian selatan dan barat laut (Djuri, 1995; Silitonga, 1973).

Kemunculan manifestasi panas bumi di daerah penelitian berada di daerah yang tersusun oleh batuan hasil gunung api muda tak teruraikan (Qyu) berumur Kuarter dengan litologi pasir tufaan, lapili, breksi, aglomerat dan aliran lava muda bersifat basaltik tersebar di bagian barat daya dan bagian tengah peta dari utara sampai selatan dan bersambung mengelilingi tubuh Gunung Tampomas (Silitonga, 2003 dalam Dirk, 2008).

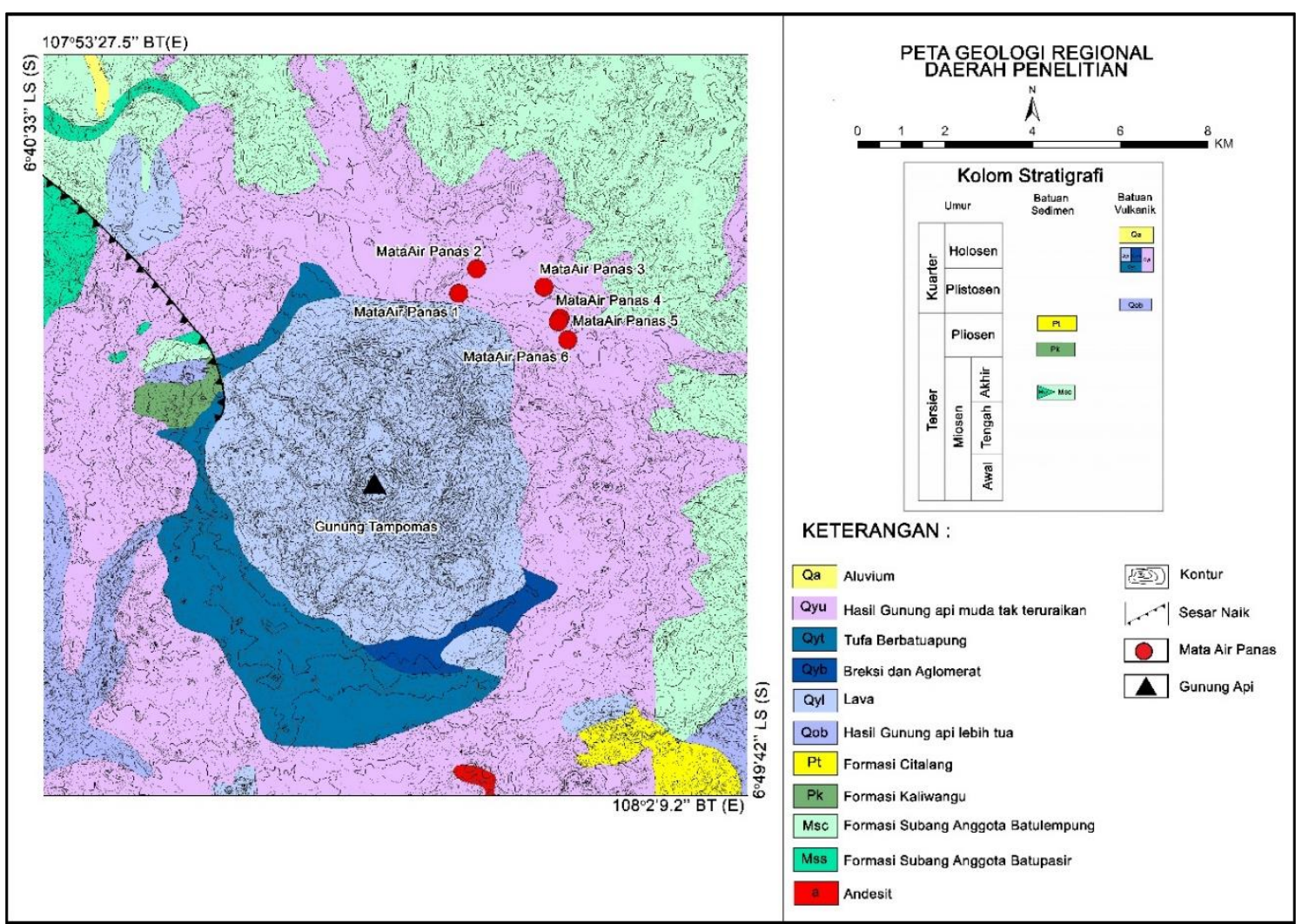

Gambar 3. Geologi regional daerah penelitian, modifikasi peta geologi lembar Bandung (Silitonga, 1973) 


\section{Struktur Geologi Regional}

Terdapat 4 kelompok utama arah jalur sesar yang berkembang di Pulau Jawa bagian barat (Haryanto dan Hilmi, 2008) yaitu:

a. Sesar berarah utara-selatan (Pola Sunda), terbentuk pada kala Paleogen dan bersifat transtensional, terdapat di wilayah Bogor dan Sukabumi menerus hingga Rangkasbitung dan Lebak. Aktivitas tektonik ini menghasilkan horst dan graben yang dikontrol oleh sesar mendatar normal.

b. Sesar berarah barat laut-tenggara (Pola Sumatra), teramati pada daerah kelurusan lembah Sungai Citanduy menerus ke arah barat melalui Kuningan dan Majalengka dan Jampang Kulon. Sesar ini diwakili oleh Sesar Citanduy yang bersifat mendatar dekstral dan Sesar Naik Baribis.

c. Sesar berarah timur laut-barat daya (Pola Meratus), diwakili oleh Sesar Cimandiri, Sesar Pelabuhanratu dan Sesar Jampang Kulon, yang merupakan sesar mendatar sinistral.

d. Sesar berarah barat-timur (Pola Jawa), diwakili oleh Sesar Naik Baribis, dijumpai pada daerah Subang menerus hingga Majalengka.

Secara regional daerah penelitian memiliki tegasan yang searah dengan pola Sumatra yang diwakili sesar-sesar naik seperti Sesar Baribis dan Sesar Citanduy. Di bagian barat laut daerah penelitian terdapat sesar naik dengan arah relatif barat laut-tenggara, sedangkan di bagian timur laut terdapat sesar naik dengan arah relatif timur laut - barat daya. Anjakan dan perlipatan relatif berarah barat lauttenggara hadir pada Formasi Subang dan sedimen Tersier lainnya.

\section{HASIL DAN PEMBAHASAN}

Hasil penelitian diuraikan berdasarkan pengolahan data dan analisis terhadap data geologi khususnya aspek morfologi, struktur geologi dan manifestasi panas bumi baik dari hasil interpretasi atau analisis di studio (laboratorium) serta hasil pengamatan di lapangan.

\section{HASIL PENGAMATAN LAPANGAN}

\section{Geomorfologi}

Daerah penelitian secara umum menggambarkan bentang alam puncak gunung api Gunung Tampomas membentuk pegunungan dengan lereng dinding yang curam. Kelurusan punggungan pada kaki Gunung Tampomas mencerminkan suatu aktivitas tektonik berupa pengangkatan atau pensesaran seperti pada Gambar 4. Berdasarkan klasifikasi pola pengaliran sungai (Twidale, 2004), pola aliran sungai di daerah penelitian terbagi menjadi tiga jenis yaitu; pola aliran sungai radial, subparalel dan dendritik. Di lapangan, pada daerah yang memiliki pola aliran sungai sub-paralel terdapat kelokan sungai yang tajam, hal ini merupakan salah satu indikasi daerah tersebut terganggu oleh struktur geologi sehingga membentuk rekahan pada batuan dan berperan sebagai media munculnya mata air panas ke permukaan dari sistem panas bumi di bawah permukaan (reservoar).

\section{Struktur Geologi}

Di lapangan, struktur geologi diindikasikan oleh fenomena morfologi atau bentang alam yang membentuk faset segitiga (triangular facet), kelurusan punggungan dan lembah yang memiliki tebing punggungan yang curam atau tajam membentuk gawir sesar (escarpment) (Gambar 6). Terbentuknya fenomena bentang alam tersebut menandakan di daerah penelitian telah terganggu oleh adanya aktivitas tektonik berupa pengangkatan (uplift), deformasi atau pensesaran. Kemunculan mata air panas pada daerah tepi punggungan memperkuat bahwa kemunculan manifestasi panas bumi berupa mata air panas tersebut dikontrol oleh struktur geologi (patahan) yang berkembang di daerah penelitian. Daerah patahan merupakan daerah rentan yang membentuk rekahan-rekahan pada batuan atau membentuk zona lemah merupakan 


\section{MAKALAH ILMIAH}

zona permeabilitas tinggi yang berperan sebagai media meloloskan fluida dari batuan yang awalnya bersifat tidak dapat meloloskan (impermeable) menjadi dapat meloloskan fluida (permeable). Pada daerah ini umumnya batuan bersifat rentan sehingga cenderung mudah mengalami pelapukan dan erosi. Pada daerah panas bumi yang memiliki pola kelurusan semakin banyak dan saling berpotongan dapat menjadi indikasi bahwa daerah tersebut rentan terhadap proses deformasi dan berpengaruh terhadap kemunculan manifestasi panas bumi permukaan. Hasil uji arah kelurusan punggungan dan arah segmen sungai memperlihatkan pola pengaliran dikontrol oleh tektonik atau struktur geologi (Gentana, 2018).

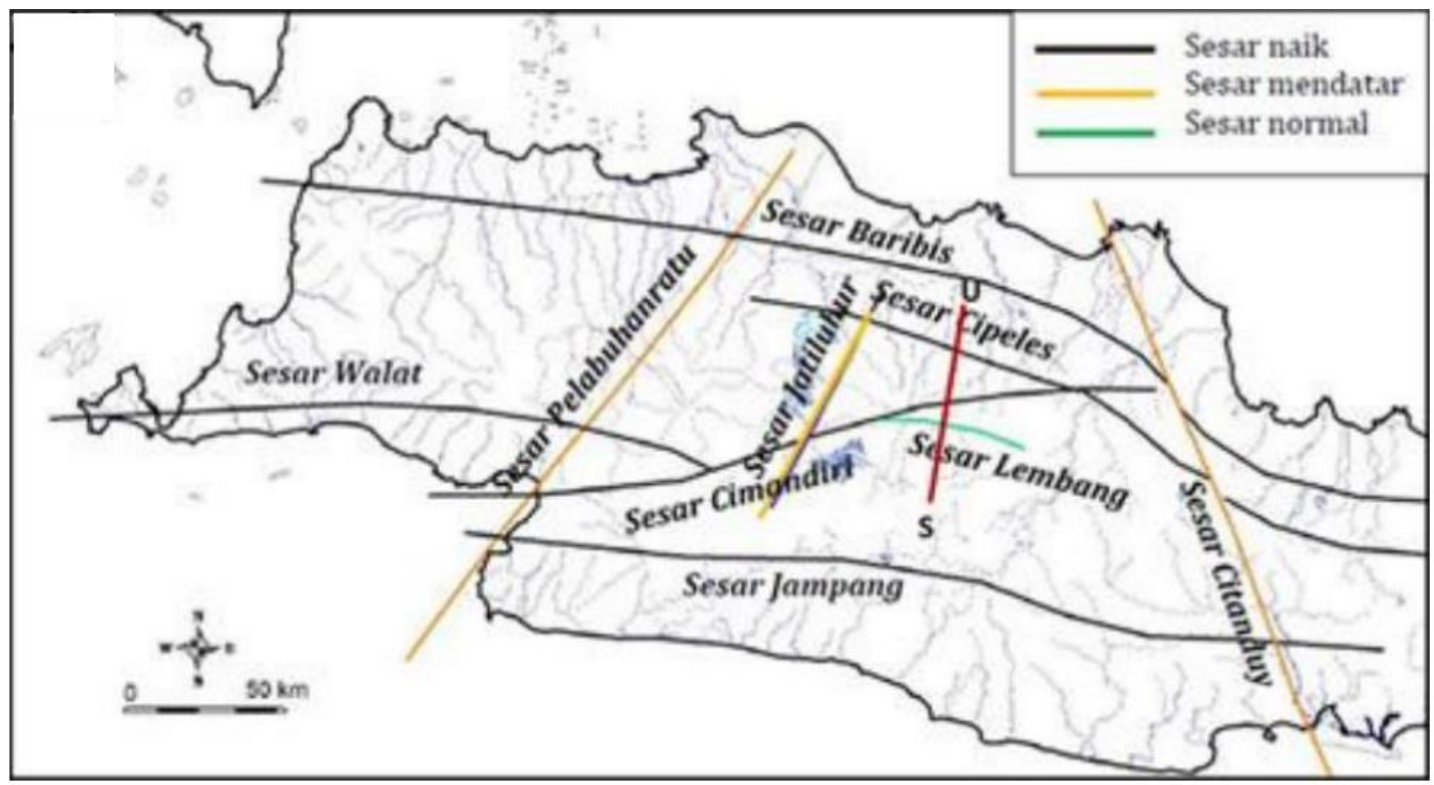

Gambar 4. Peta pola struktur regional Jawa Barat

(Haryanto, 2014 dalam Febyani dan Pradhana et al., 2020)

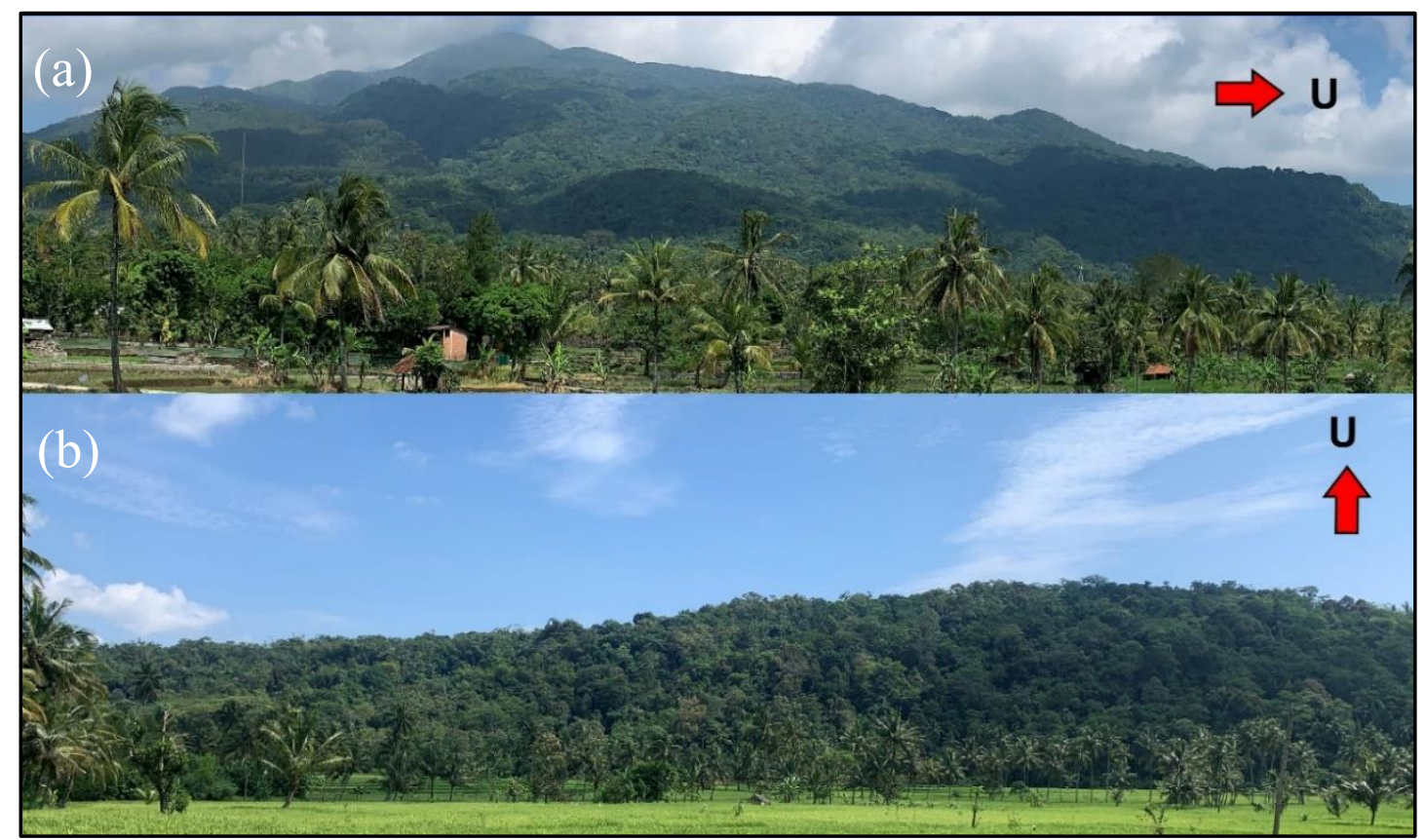

Gambar 5. (a) Bentang alam Gunung Tampomas,

(b) Punggungan pada kaki Gunung Tampomas 


\section{MAKALAH ILMIAH}

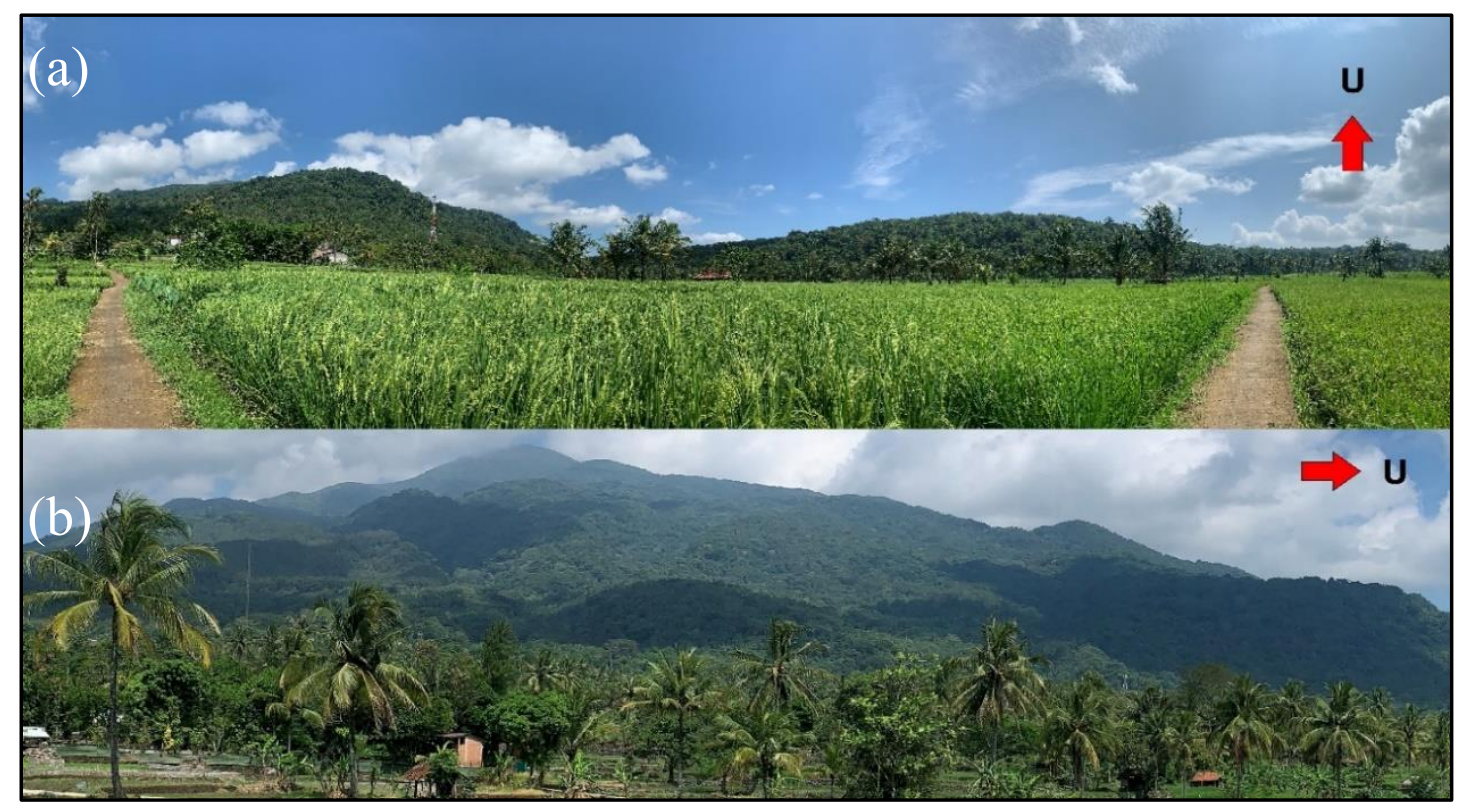

Gambar 6. (a) Fenomena morfologi kelurusan punggungan di kaki Gunung Tampomas (b) Morfologi faset segitiga dengan tebing punggungan yang curam

\section{Sebaran Manifestasi Panas Bumi}

Manifestasi panas bumi di daerah penelitian berupa mata air panas (Gambar 7) yang disebut sebagai mata air panas:

a. Cikeresek 1 terletak di tengah sawah dengan elevasi $309 \mathrm{mdpl}$ di Dusun Cikeresek Desa Sekarwangi, karakteristik fisik berwarna keruh, berasa, berbau, bersuhu $44^{\circ} \mathrm{C}$ dan $\mathrm{pH}$ 5,6 .

b. Cikeresek 2 terletak di tengah sawah dengan elevasi 309 mdpl di Dusun Cikeresek Desa Sekarwangi, karakteristik fisik berwarna jernih, berasa, berbau, bersuhu $44^{\circ} \mathrm{C}$ dan $\mathrm{pH}$ 5,7 .

c. Cipanas Sekarwangi yang merupakan tempat wisata pemandian air panas dengan elevasi $342 \mathrm{mdpl}$ Dusun Conggeang Desa Sekarwangi, karakteristik sifat fisiknya berwarna jernih, berbau belerang, tidak berasa, memiliki temperatur $49^{\circ} \mathrm{C}$ dan $\mathrm{pH} 6,36$.

d. Bojong yang merupakan tempat wisata pemandian air panas tepatnya di samping jalan raya dengan elevasi 308 mdpl di Dusun Bojong Desa Cibubuan. karakteristik fisiknya berwarna jernih, berbau, berasa, memiliki suhu $37^{\circ} \mathrm{C}$ dan $\mathrm{pH} 7,54$. e. Cipanas Cileungsing 1 terletak di tengah persawahan dengan elevasi 308 mdpl di Desa Cileungsing, karakteristik fisiknya berwarna jernih, berbau, berasa, memiliki suhu $45^{\circ} \mathrm{C}$ dan $\mathrm{pH} 6,33$.

f. Cipanas Cileungsing 2 berada di Desa Cileungsing, merupakan tempat wisata pemandian air panas dengan elevasi 308 mdpl, karakteristik fisiknya berwarna jernih, tidak berbau, berasa, memiliki suhu $47^{\circ} \mathrm{C}$ dan $\mathrm{pH} 6,41$.

Masing-masing sifat fisik dari enam lokasi mata air panas memiliki sifat fisik yang berbeda-beda, yaitu memiliki $\mathrm{pH}$ air panas yang bervariasi dari sedikit asam hingga mendekati basa, berbau dan tidak berbau, berasa dan tidak berasa dengan suhu air panas berkisar dari $37^{\circ} \mathrm{C}$ hingga $49^{\circ} \mathrm{C}$. Mata air panas terbentuk karena adanya aliran panas dari bawah permukaan melalui rekahan-rekahan batuan.

Berdasarkan data hasil perhitungan geotermometer dengan rumus Giggenbach (1988) menggunakan rasio kimia seperti $\mathrm{Na} / \mathrm{K}$ pada lokasi manifestasi yang sama (Prasetio dan Laksminingpuri et al., 2018), menghasilkan temperatur bawah permukaan yang relatif tinggi antara $183^{\circ} \mathrm{C}$ hingga $221^{\circ} \mathrm{C}$ (Tabel 1$)$. 


\section{MAKALAH ILMIAH}

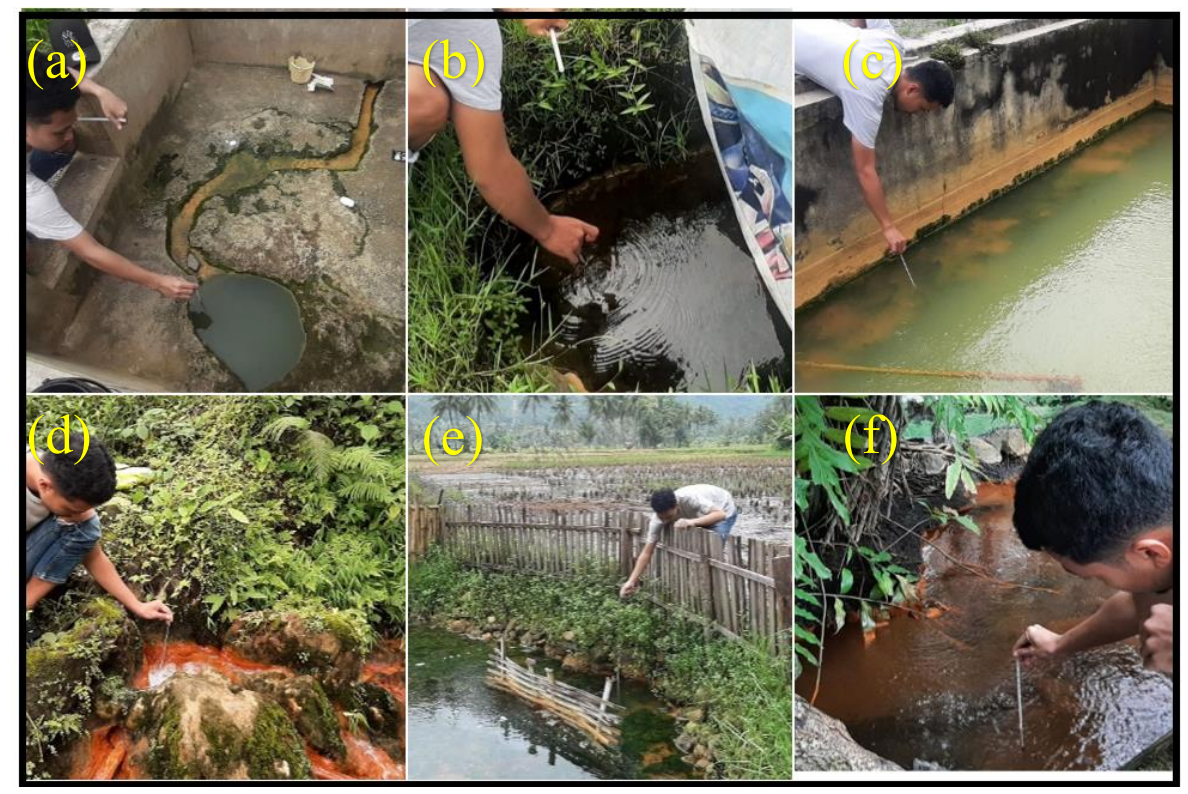

Gambar 7. (a) Mata air panas Cikeresek, (b) Mata air panas Cikeresek 2

(c) Mata air panas Cipanas Sekarwangi, (d) Mata air panas Bojong,

(e) Mata air panas Cileungsing 1, (f) Mata air panas Cileungsing 2

Tabel 1. Koordinat lokasi manifestasi, jenis manifestasi dan temperatur bawah permukaan.

\begin{tabular}{|c|c|c|c|c|c|}
\hline No. & Kode & Lokasi & Koordinat & Jenis Manifestasi & $\begin{array}{c}\text { Temperatur Bawah } \\
\text { Permukaan }\left(\mathbf{C}^{\circ}\right)\end{array}$ \\
\hline 1 & Mata Air Panas 1 & Cileungsing & $\begin{array}{c}107^{\circ} 58^{\prime} 35,7^{\prime \prime} \mathrm{E} \\
6^{\circ} 43^{\prime} 29,6^{\prime \prime} \mathrm{S}\end{array}$ & Mata Air Panas & 189 \\
\hline 2 & Mata Air Panas 2 & Cileungsing & $\begin{array}{l}107^{\circ} 58^{\prime} 49^{\prime \prime} \mathrm{E} \\
6^{\circ} 43^{\prime} 11,4^{\prime \prime} \mathrm{S}\end{array}$ & Mata Air Panas & 183 \\
\hline 3 & Mata Air Panas 3 & Bojong & $\begin{array}{c}107^{\circ} 59^{\prime} 39^{\prime \prime} \mathrm{E} \\
6^{\circ} 43^{\prime} 25^{\prime \prime} \mathrm{S}\end{array}$ & Mata Air Panas & 220 \\
\hline 4 & Mata Air Panas 4 & Cikeresek & $\begin{array}{c}107^{\circ} 59^{\prime} 51^{\prime \prime} \mathrm{E} \\
6^{\circ} 43^{\prime} 48^{\prime \prime} \mathrm{S}\end{array}$ & Mata Air Panas & - \\
\hline 5 & Mata Air Panas 5 & Cikeresek & $\begin{array}{c}107^{\circ} 59^{\prime} 49,5^{\prime \prime} \mathrm{E} \\
6^{\circ} 43^{\prime} 51^{\prime \prime} \mathrm{S}\end{array}$ & Mata Air Panas & - \\
\hline 6 & Mata Air Panas 6 & Sekarwangi & $\begin{array}{c}107^{\circ} 59^{\prime} 56,5^{\prime \prime} \mathrm{E} \\
6^{\circ} 43^{\prime} 4,0^{\prime \prime} \mathrm{S}\end{array}$ & Mata Air Panas & 221 \\
\hline
\end{tabular}

\section{HASIL ANALISIS STUDIO}

\section{Analisis Penginderaan jauh}

Interpretasi penginderaan jauh dilakukan dengan penyinaran 4 (empat) sudut berbeda yaitu pada azimut: $0^{\circ}, 45^{\circ}, 90^{\circ}$, $135^{\circ}$, dan penyinaran konstan $45^{\circ}$. Kemudian diplot pada diagram roset untuk mengetahui orientasi pola utama kelurusan punggungan dari masingmasing sudut penyinaran sebagai berikut:

a. Kelurusan ASTER GDEM azimut penyinaran $0^{\circ}$, memiliki pola utama kelurusan punggungan-lembah memiliki arah relatif barat-timur (Gambar 8). b. Kelurusan ASTER GDEM azimut penyinaran $45^{\circ}$, memiliki pola utama kelurusan punggungan-lembah memiliki arah relatif barat lauttenggara (Gambar 9).

c. Kelurusan ASTER GDEM azimut penyinaran $90^{\circ}$, memiliki pola utama kelurusan punggungan memiliki arah utara-selatan dan timur laut-barat daya. Kelurusan lembah memiliki arah barat laut-tenggara (Gambar 10).

d. Kelurusan ASTER GDEM azimut penyinaran $135^{\circ}$, memiliki pola utama kelurusan punggungan memiliki arah utara-selatan dan timur laut-barat daya. Kelurusan lembah memiliki arah barat laut-tenggara (Gambar 11). 
e. Kelurusan ASTER GDEM azimut penyinaran gabungan (overlay) antara $0^{\circ}, 45^{\circ}, 90^{\circ}$, dan $135^{\circ}$ memperlihatkan orientasi kelurusan secara menyeluruh dari masing-masing sudut penyinaran secara garis besar menunjukkan pola kelurusan utama di daerah penelitian memiliki arah relatif barat lauttenggara dan timur laut-barat daya yang diinterpretasikan sebagai patahan seperti ditampilkan pada Gambar 12.

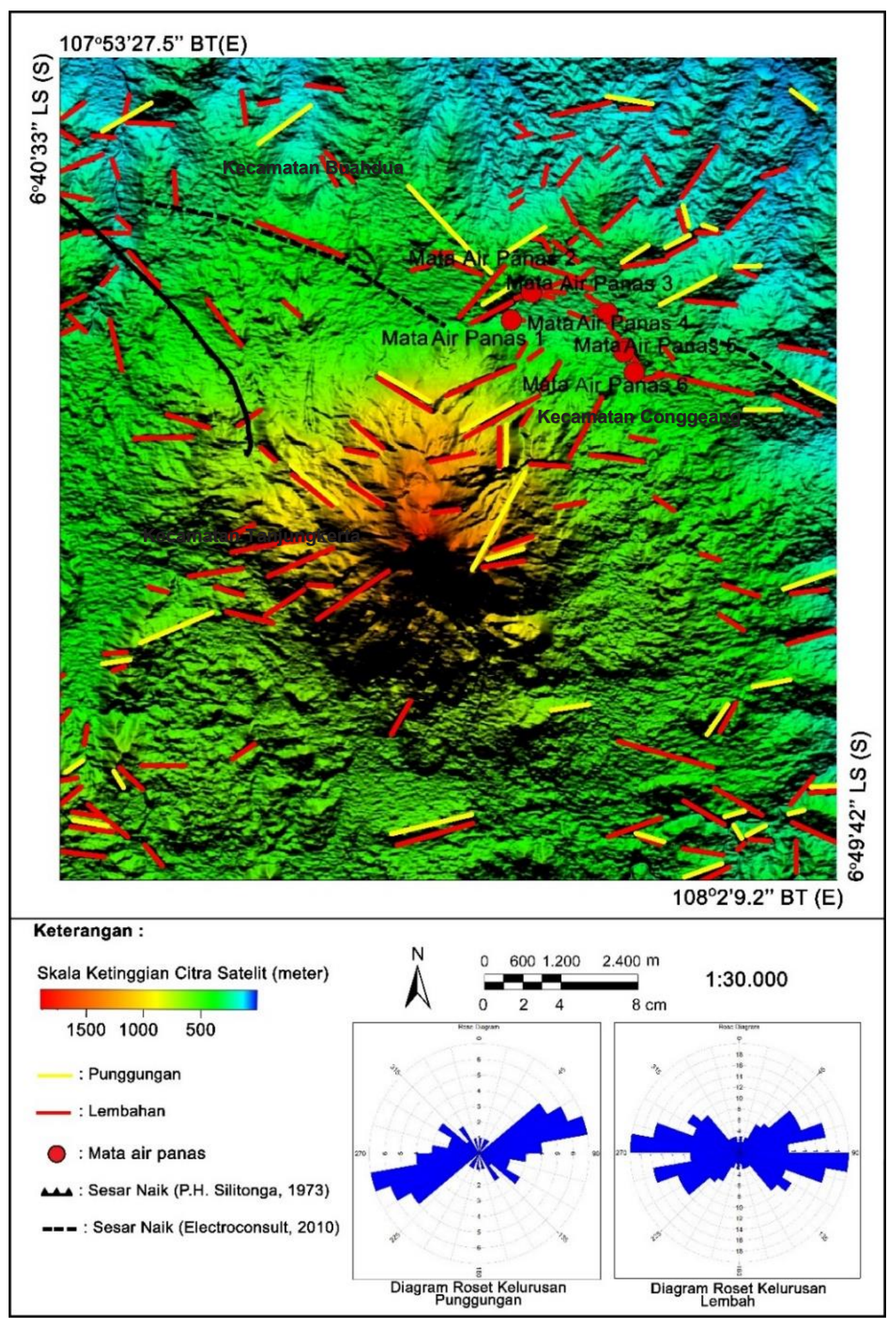

Gambar 8. Analisis kelurusan azimut penyinaran $0^{\circ}$ dan hasil plot pada diagram roset 


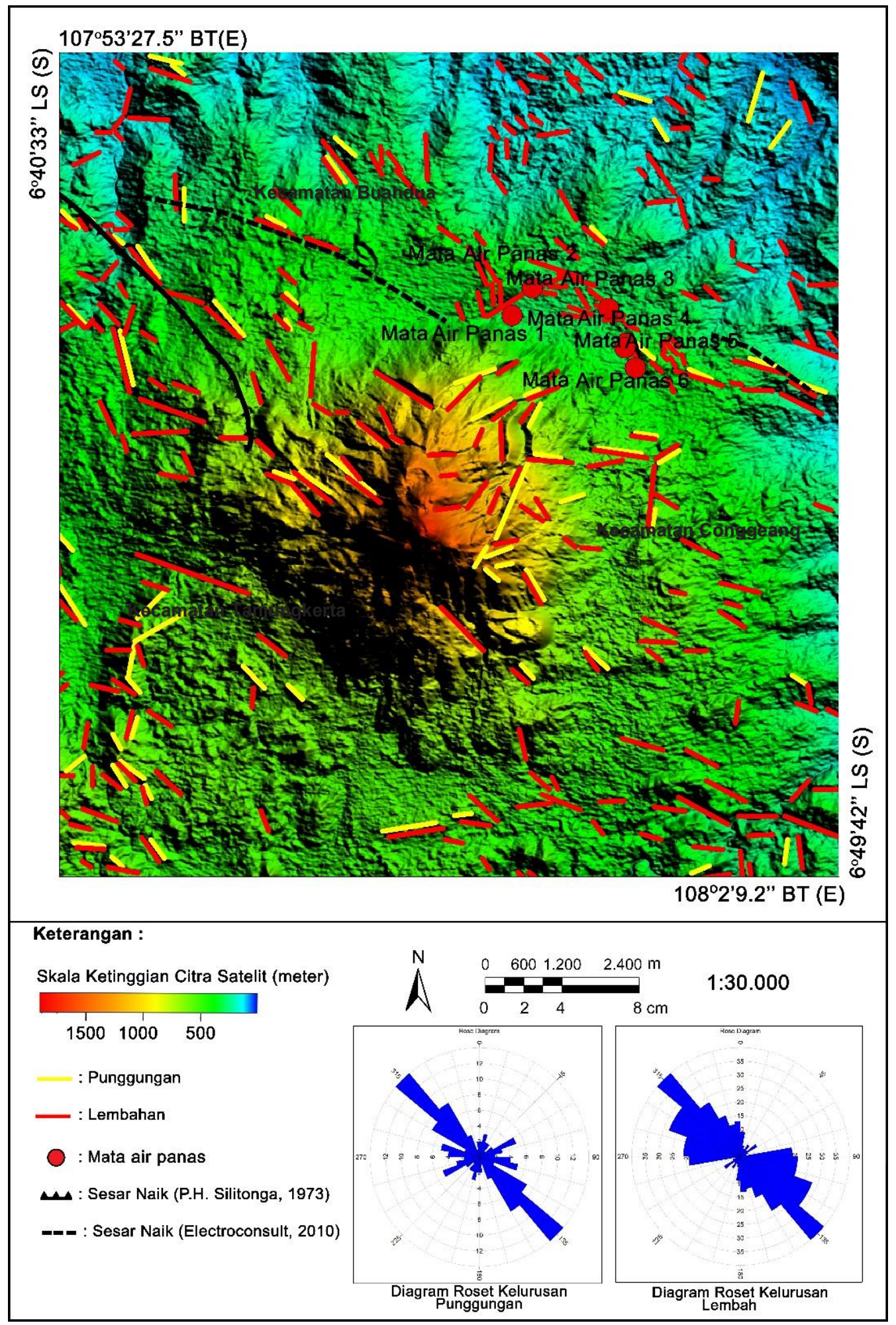

Gambar 9. Analisis kelurusan azimut penyinaran $45^{\circ}$ dan hasil plot pada diagram roset 


\section{MAKALAH ILMIAH}

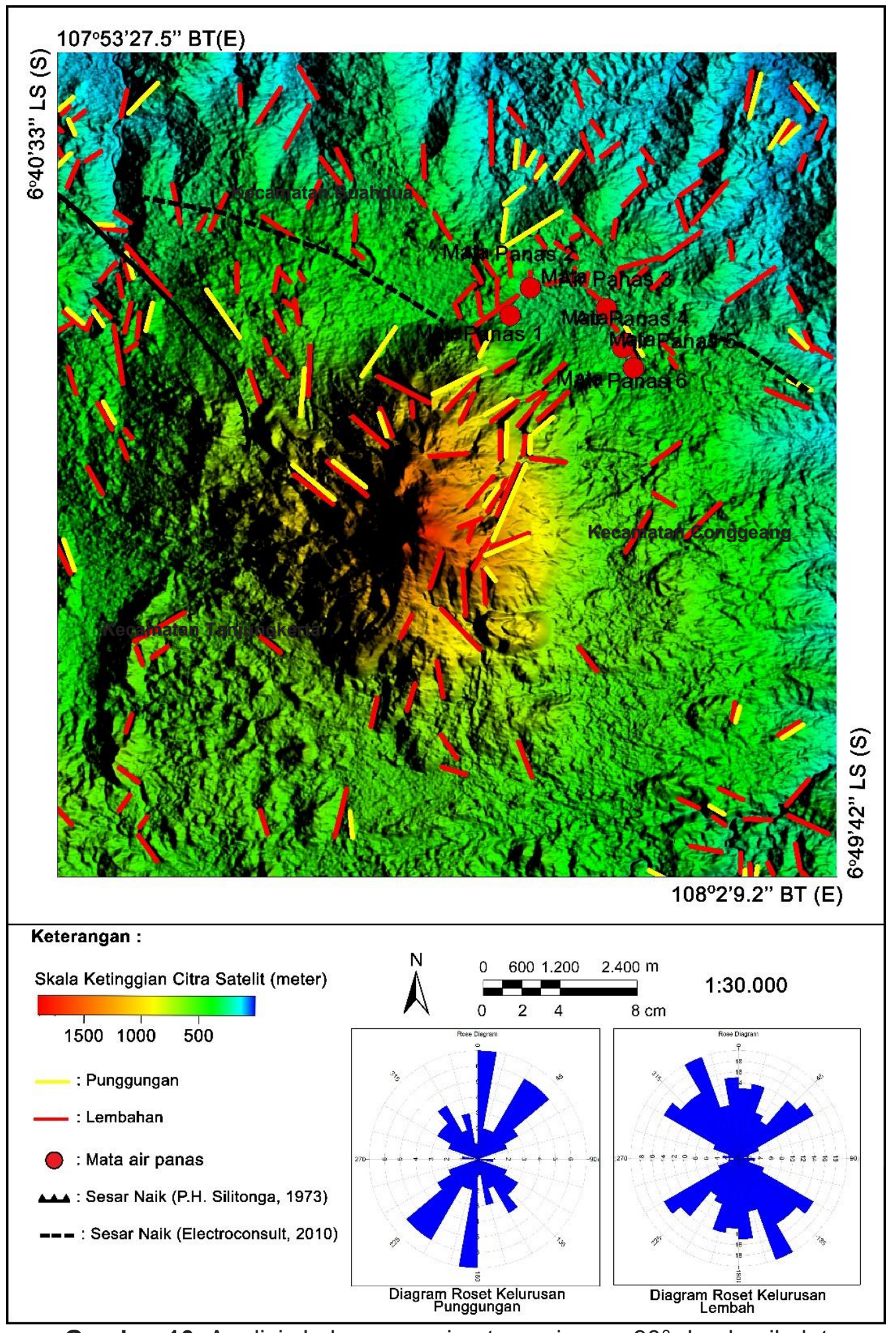

Gambar 10. Analisis kelurusan azimut penyinaran $90^{\circ}$ dan hasil plot pada diagram roset 


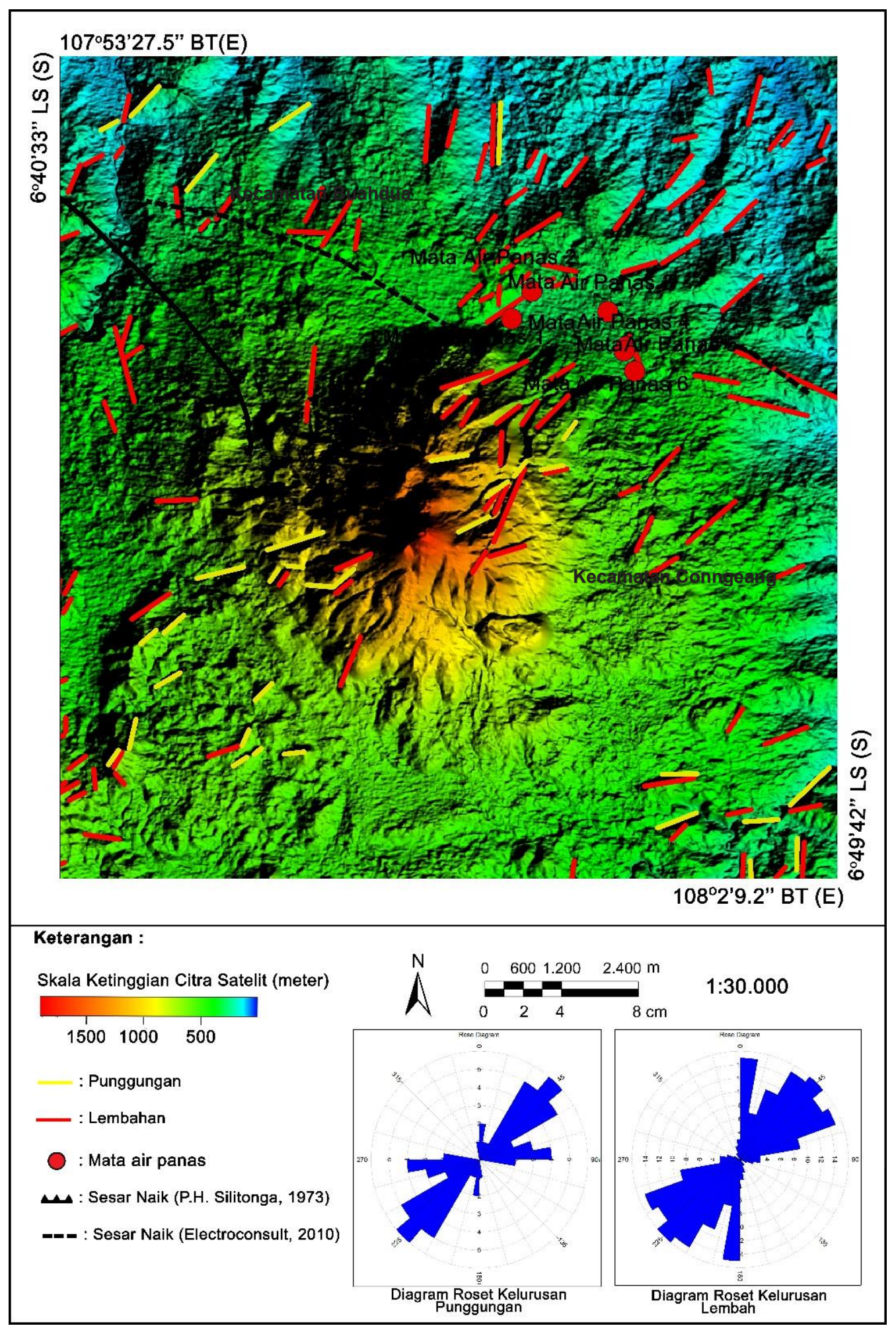

Gambar 11. Analisis kelurusan azimut penyinaran $135^{\circ}$ dan hasil plot pada diagram roset 


\section{MAKALAH ILMIAH}

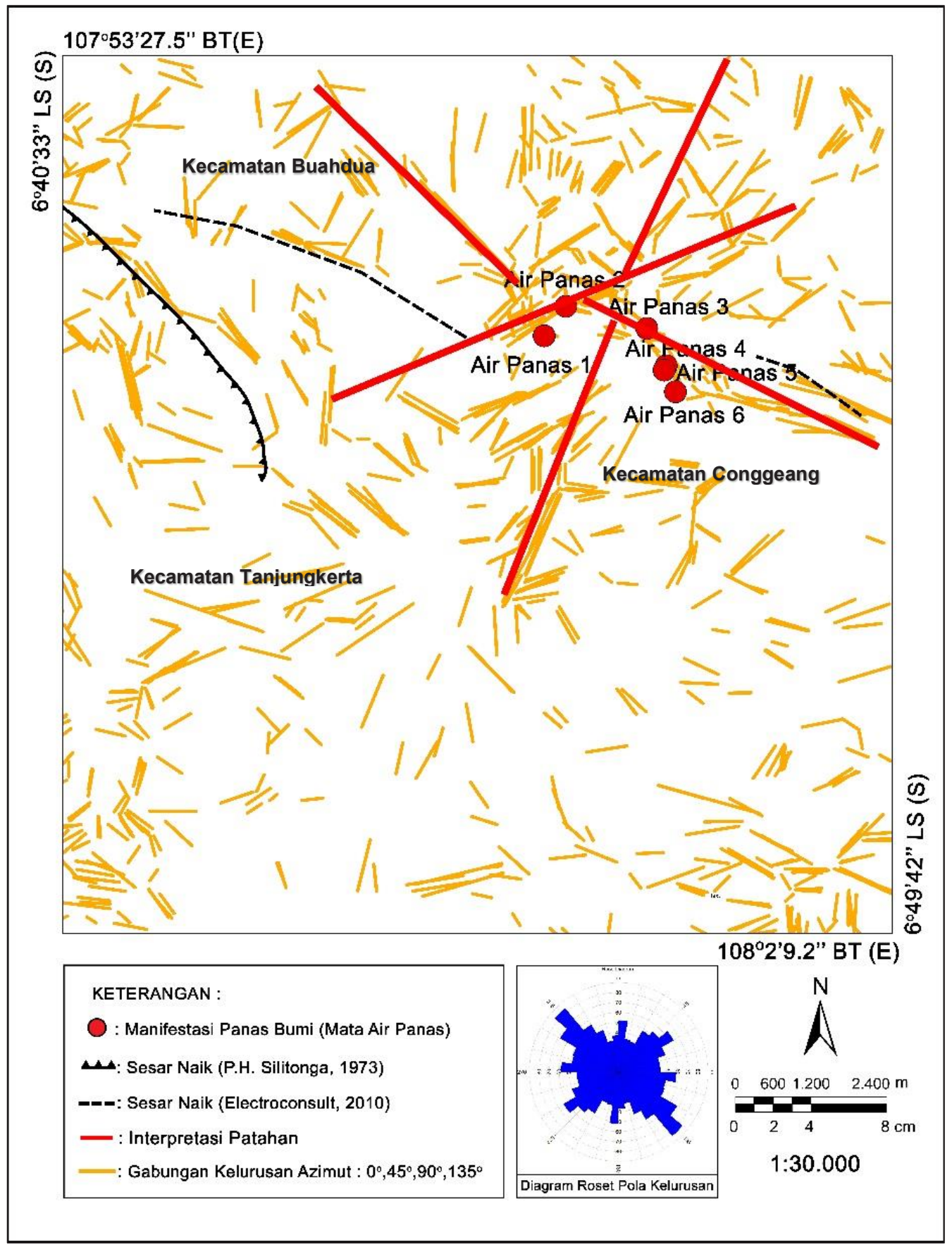

Gambar 12. Peta overlay kelurusan azimut penyinaran gabungan antara $0^{\circ}, 45^{\circ}, 90^{\circ}, 135^{\circ}$ dan hasil plot pada diagram roset

\section{Analisis Fault Fracture Density (FFD)}

Hasil analisis FFD memperlihatkan di daerah penelitian memiliki tingkat permeabilitas yang bervariasi dari rendah hingga ke tinggi berkisar; 0,00-9,33 km-1, yang diplot dalam satuan area dalam $\mathrm{km}$ atau per-grid dengan ukuran $1 \mathrm{~km} \times 1 \mathrm{~km}$ (Gambar 13). Daerah dengan nilai permeabilitas rendah memiliki nilai: 0,00
$3,00 \mathrm{~km}^{-1}$, sedang memiliki nilai: $3,00-6,00$ $\mathrm{km}^{-1}$, dan tinggi memiliki nilai: $6,00-9,33$ $\mathrm{km}^{-1}$. Nilai kerapatan patahan dan rekahan (permeabilitas) pada setiap grid kemudian dibuat kontur yang menunjukkan nilai kerapatan patahan dan rekahan yang sama, digambarkan dalam peta kontur FFD (Gambar 14). Peta kontur FFD ini yang menunjukan tingkat nilai FFD atau 


\section{MAKALAH ILMIAH}

zona permeabilitas dari rendah hingga tinggi, sebagai berikut:

1) Zona permeabilitas rendah memiliki nilai FFD $0,00-3,00 \mathrm{~km}^{-1}$, menempati bagian barat, timur, dan selatan daerah penelitian ditandai dengan warna hijau tua-hijau muda. Zona ini diinterpretasikan sebagai daerah yang sangat kecil dipengaruhi oleh struktur geologi.

2) Zona permeabilitas sedang memiliki nilai FFD 3,00-6,00 km-1, menempati bagian timur laut dan tenggara daerah penelitian ditandai dengan warna kuning muda hingga kuning tua. Zona ini diinterpretasikan sebagai daerah yang dipengaruhi oleh struktur geologi sedang (tidak terlalu intensif).

3) Zona permeabilitas tinggi memiliki nilai FFD 6,00-9,33 $\mathrm{km}^{-1}$, menempati bagian tengah dan timur laut daerah penelitian yang ditandai dengan warna jingga tua hingga merah. Zona ini diinterpretasikan sebagai daerah yang dipengaruhi oleh struktur geologi secara intensif.

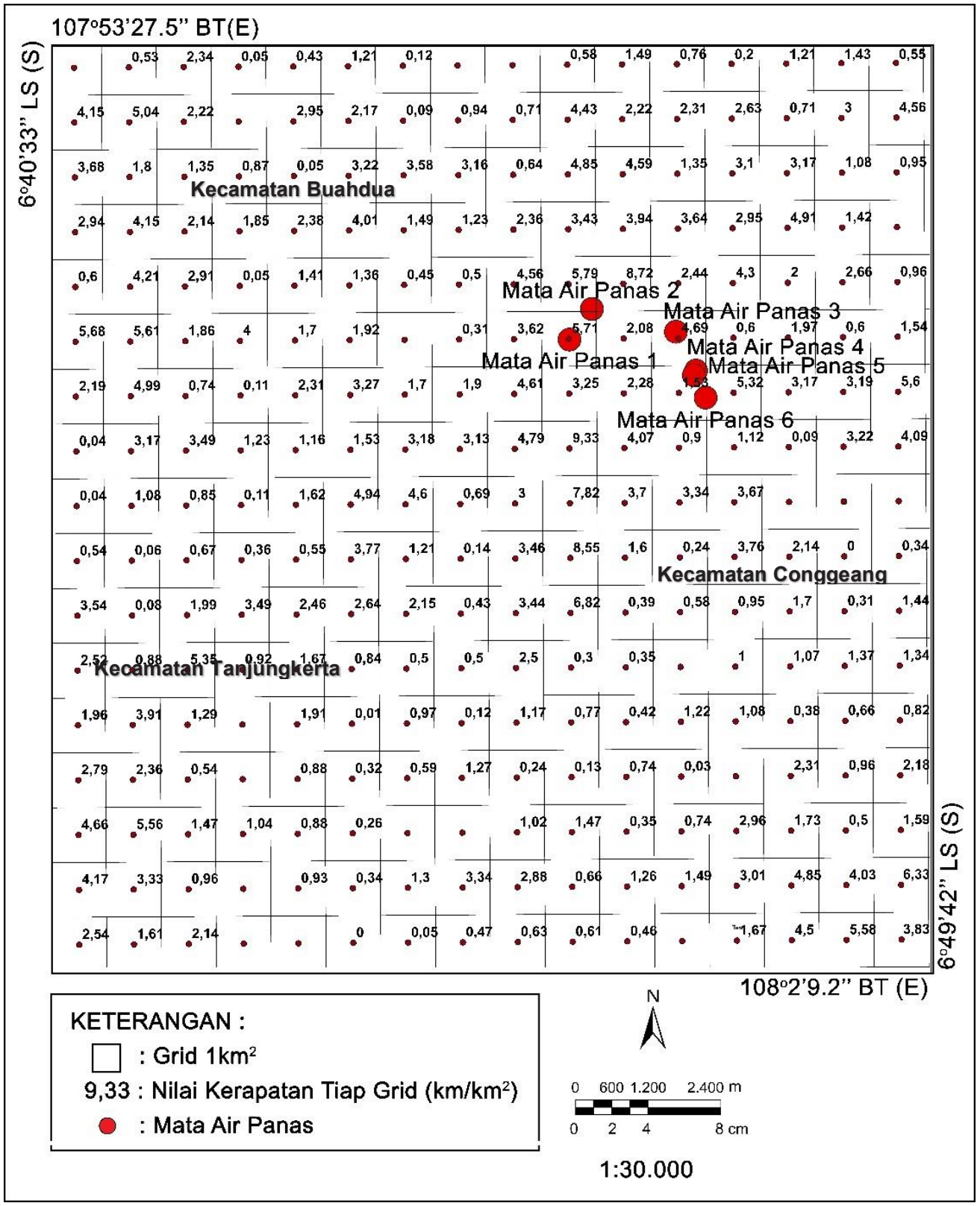

Gambar 13. Nilai hasil perhitungan Fault Fracture Density (FFD) pada setiap grid 


\section{MAKALAH ILMIAH}

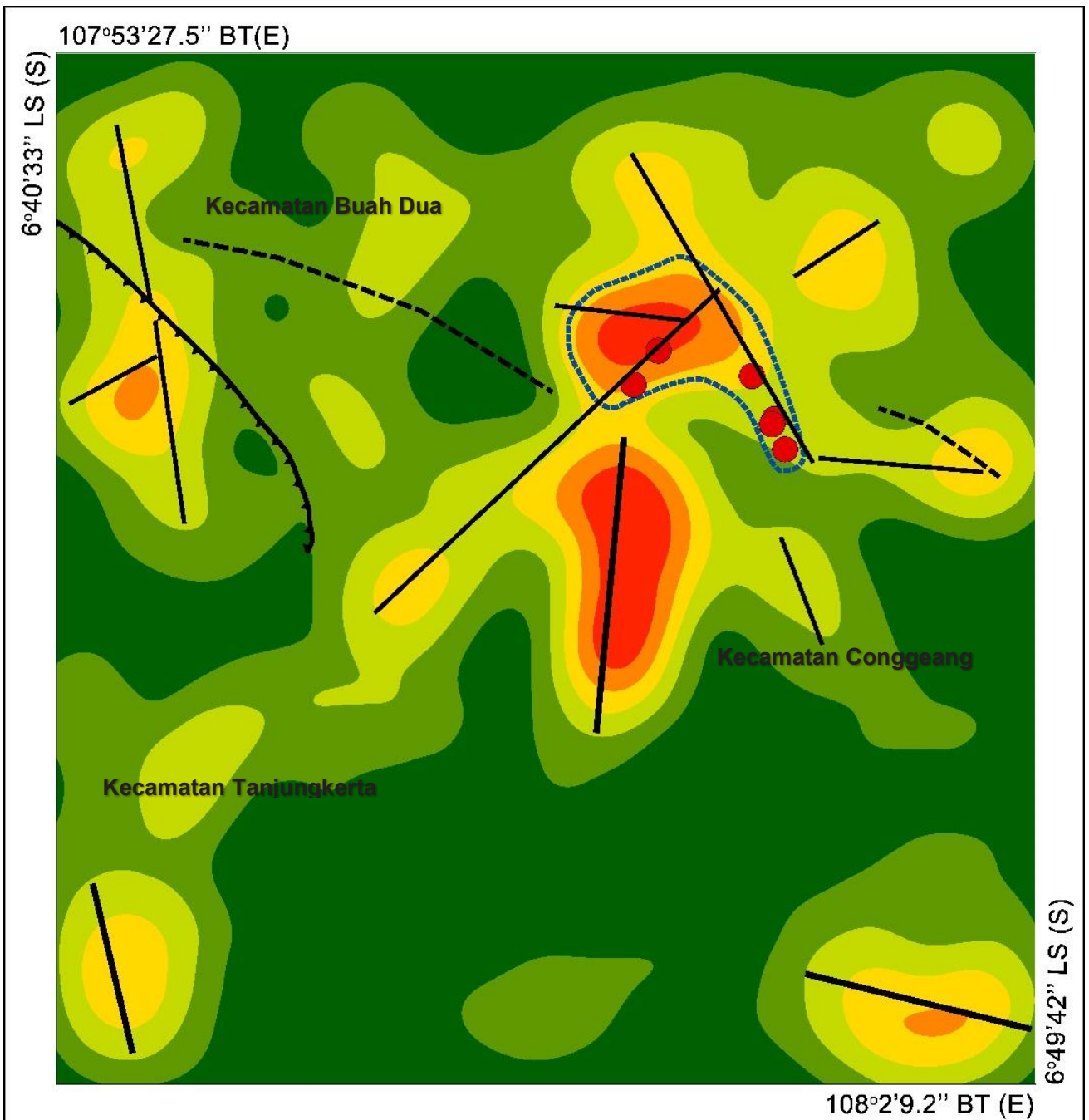

Peta Kontur Berdasarkan Analisis FFD Daerah

G. Tampomas dan Sekitarnya, Kabupaten Sumedang, Jawa Barat

\section{KETERANGAN :}

- Mata Air Panas

L. : Sesar Naik (P. H. Silitonga, 1973)

--- : Sesar Naik (Electroconsult, 2010)

— : Interpretasi Patahan

$\begin{aligned} & \text { Nilai Densitas } \\ & \left(\mathrm{km} / \mathrm{km}^{2}\right) \\ & 7,5-9,33 \\ & 6-7,5 \\ & 4,5-6 \\ & 3-4,5 \\ & 1,5-3 \\ & 0-1,5\end{aligned}$

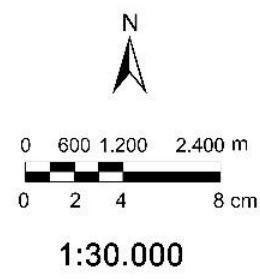

Gambar 14. Peta sebaran Densitas hasil penghitungan Fault Fracture Density

\section{Pemodelan 3D}

Penggambaran pola kelurusan punggungan-lembah yang diinterpretasikan sebagai patahan terhadap hasil plot keberadaan manifestasi panas bumi di permukaan dalam bentuk 2 dimensi (Gambar 15) dan 3 dimensi (Gambar 16) dengan menggunakan Micromine software memperlihatkan secara jelas kemunculan manifestasi panas bumi berhubungan atau difasilitasi oleh adanya patahan-patahan yang berkembang di daerah penelitian dengan orientasi pola utama berarah barat laut-tenggara dan timur laut-barat daya. 


\section{MAKALAH ILMIAH}

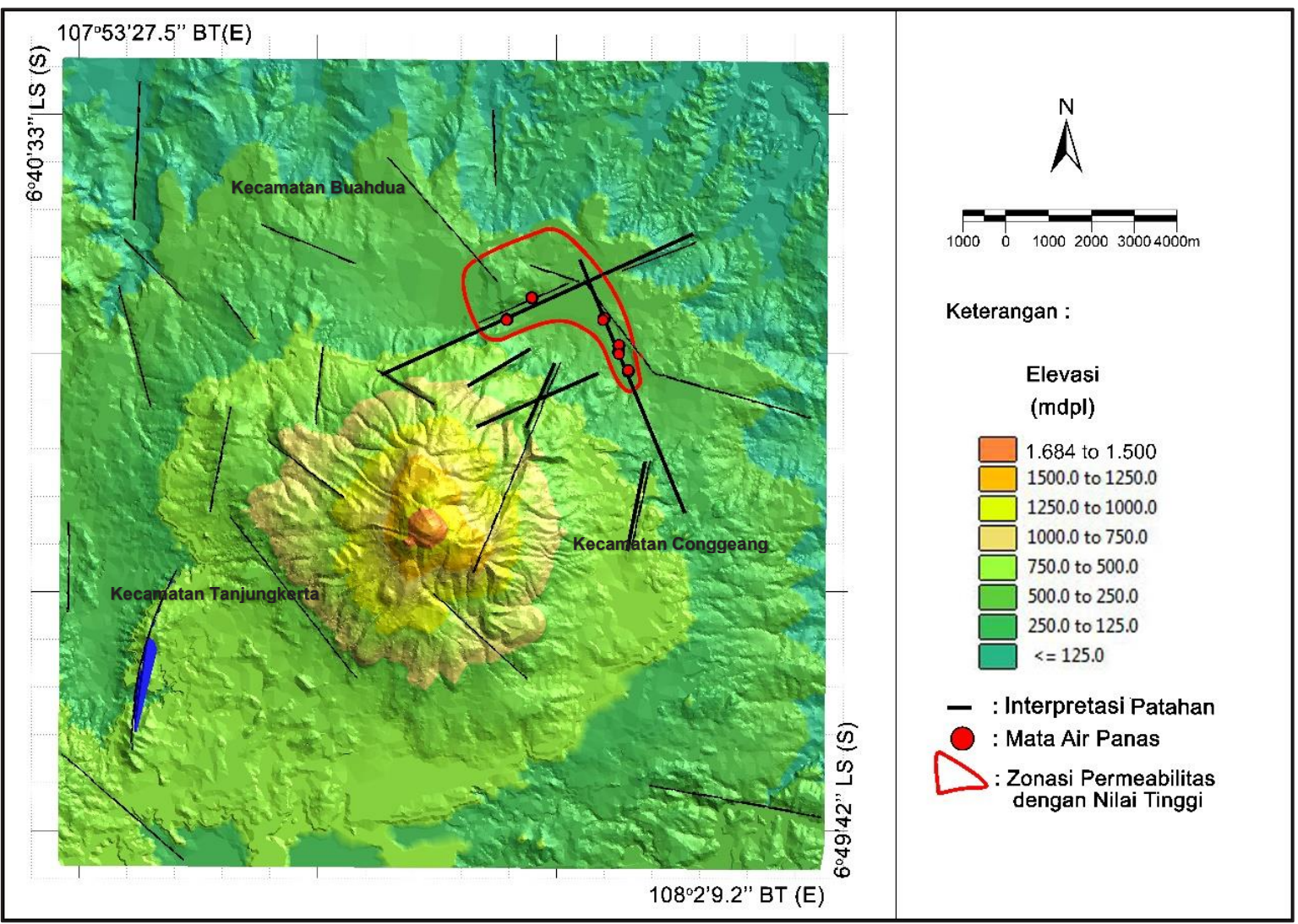

Gambar 15. Hasil pemodelan 2D micromine software

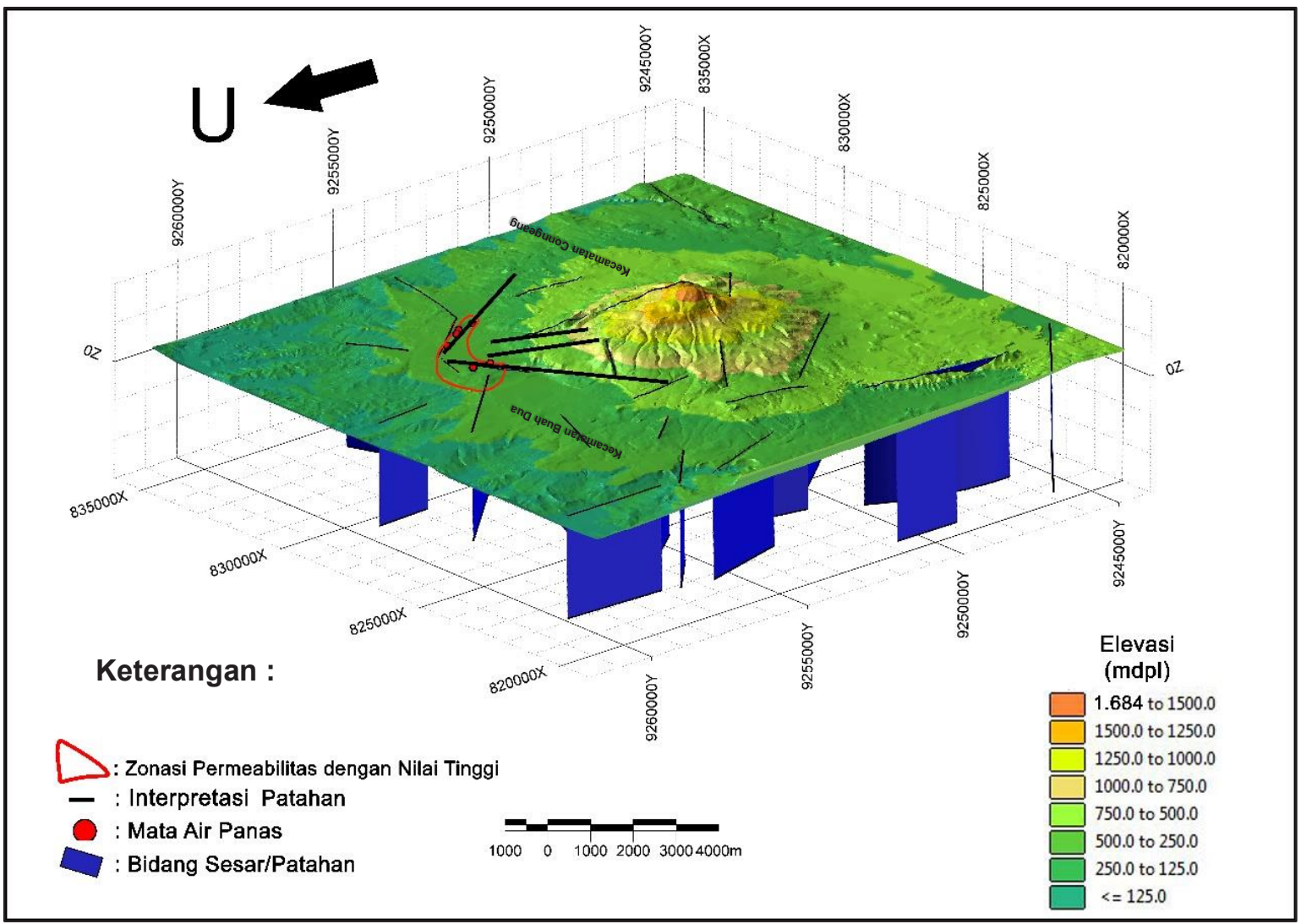

Gambar 16. Hasil pemodelan 3D micromine software 


\section{PEMBAHASAN}

Fenomena morfologi atau bentang alam di lapangan memperlihatkan bentang alam puncak gunung api yang memiliki kemiringan lereng curam. Pola pengaliran sungai sub-paralel mendominasi daerah penelitian yang diekspresikan oleh bentang alam kelurusan-kelurusan punggungan dan lembah yang memanjang.

Indikasi struktur geologi di lapangan berupa faset segitiga (triangular facet), punggungan dan lembah yang memiliki tebing curam/terjal membentuk gawir sesar (escarpment) yang diperkirakan sebagai jalur patahan yang memfasilitasi fluida dalam reservoar mengalir hingga permukaan.

Hasil penarikan kelurusan dari masingmasing 4 sudut penyinaran menunjukan pola utama kelurusan punggunganlembah yang diinterpretasikan sebagai patahan secara menyeluruh memiliki arah dominan barat laut - tenggara dan timur laut-barat daya. Pola utama kelurusan punggungan-lembah di daerah penelitian memiliki pola yang relatif sama dengan pola struktur regional Jawa Barat yaitu pola Sumatra yang memiliki arah relatif barat laut-tenggara (Haryanto dan Hilmi, 2008). Patahan-patahan tersebut berasosiasi dengan kemunculan mata air panas dengan temperatur bawah permukaan relatif tinggi yang membentuk sistem panas bumi di daerah Gunung Tampomas.

Penentuan zona permeabilitas dengan menggunakan metode Fault Fracture Density (FFD) dilakukan kemudian ditampilkan berupa peta kontur FFD (Gambar 14). Intensitas kerapatan patahan dan rekahan yang tinggi menunjukkan tingkat permeabilitas yang tinggi. Daerah panas bumi Gunung Tampomas dapat dikelompokkan menjadi 4 tingkat zona permeabilitas, yaitu permeabilitas rendah $\left(0,00-3,00 \quad \mathrm{~km}^{-1}\right)$ ditandai dengan warna hijau tua hingga hijau muda, permeabilitas sedang (3,00-
6,00 $\mathrm{km}^{-1}$ ) ditandai dengan warna kuning muda hingga kuning tua dan permeabilitas tinggi $\left(6,00-9,33 \mathrm{~km}^{-1}\right)$ yang ditandai dengan warna jingga tua hingga merah. Daerah yang memiliki nilai permeabilitas yang tinggi berada pada bagian timur laut Gunung Tampomas (Gambar 14).

Selanjutnya, data hasil analisis FFD dikompilasi dengan lokasi kemunculan manifestasi mata air panas dan data struktur geologi berupa kelurusan punggungan dan lembah dari hasil analisis penginderaan jauh. Menunjukkan korelasi yang baik, seperti yang ditampilkan pada pemodelan 3D (Gambar 16). Pemodelan $3 D$ memperlihatkan secara jelas kemunculan mata air panas dengan temperatur bawah permukaan relatif tinggi berada pada zona permeabilitas dengan nilai tinggi dan tepi atau perpotongan garis-garis patahan beririsan dengan orientasi pola utama berarah barat lauttenggara dan timur laut-barat daya.

Jika dibandingkan dengan hasil survei deteksi distribusi permeabilitas menggunakan konsentrasi Radon-222 dalam gas tanah (Prasetio dan Laksminingpuri et al., 2020), menunjukkan lokasi pengukuran yang berada di dekat mata air panas memiliki konsentrasi ${ }^{222} \mathrm{Rn}$ terukur tinggi dan anomali atau diatas ambang nilai konsentrasi tinggi Radon222. Hal ini menunjukkan bahwa daerah zona permeabilitas dengan nilai tertinggi dari peta kontur FFD mendukung hasil penelitian tersebut.

Penelitian ini menggunakan metode penginderaan jauh, FFD, dan pemodelan $3 D$ menunjukkan kontrol struktur geologi berpengaruh terhadap pembentukan zona permeabilitas dan kemunculan manifestasi panas bumi. Data hasil perhitungan dengan metode ini dapat menjadi pertimbangan dalam kegiatan eksplorasi lebih lanjut.

\section{KESIMPULAN}

Morfologi daerah penelitian memperlihatkan bentang alam puncak 
gunung api dengan dinding lereng curam dan kelurusan punggungan lembah tebing curam yang dipengaruhi oleh struktur geologi berupa patahan atau sesar dengan arah dominan barat laut-tenggara dan timur laut-barat daya.

Hasil analisis kerapatan patahan dan rekahan dengan metode FFD memperlihatkan daerah bagian timur laut Gunung Tampomas yaitu pada lokasi kemunculan manifestasi memiliki tingkat kerapatan dan rekahan yang tinggi. Hal ini mengekspresikan patahan membentuk zona permeabel memungkinkan sebagai tempat sirkulasi fluida masuk (recharges area) ke reservoar dan kemudian keluar (discharges area) sebagai fluida panas bumi ke permukaan berupa manifestasi mata air panas permukaan.

Daerah dengan zona permeabilitas tinggi dapat menjadi daerah prospek untuk diteliti lebih lanjut. Disarankan agar dilakukan penelitian lanjutan khususnya dengan melakukan pengukuran kekar atau cermin sesar sehingga diperoleh data arah dan jenis sesar, serta pola hidrologi (hydrology flow) pada daerah prospek tersebut.

\section{UCAPAN TERIMAKASIH}

Ucapan terimakasih penulis ucapkan kepada kepada Fakultas Teknik Geologi, Universitas Padjadjaran dan semua pihak yang telah memberikan dukungan dalam penyelesaian tulisan ini.

\section{DAFTAR PUSTAKA}

Anonim,. 2020. Current Geothermal Landscape and Government Objective for Future Development [Dokumen PDF]. Direktorat Jenderal Energi Baru, Terbarukan, dan Konservasi Energi Diperoleh dari Catatan Kuliah online.

Provinsi Jawa Parat Indonesia Geospatial Portal. Portal Geospasial Indonesia. Diakses pada 15 Oktober 2020.
Dirk, H. J. M. 2008. 'Petrologi - geokimia Batuan Gunung Api Tampomas dan sekitarnya'. Jurnal Geologi Indonesia. Vol. 3, no. 1, hal. 23-35.

Febyani, S., Pradhana K.M.F., Rivaldy, M., Syafri, I., Nur, A.A, Embara, P. \& Nugroho, S.D. 2020. 'Analisis Kerentanan Gempa pada Jalur Sesar Baribis Menggunakan Metode Microearthquake (Meq)'. Bulletin of Scientific Contribution Geology. Vol. 18 , no. 1, hal. 1-12.

Gentana, D., Sukiyah, E., Sulaksana, N \& Yuningsih, E.N 2017, 'Determination Tanggamus Geothermal Prospect Area, Lampung Province, South Sumatra Based on Remote Sensing and 3D Micromine Software', FIG Working Week, Helsinki, Finland, May 29-June 2, 2017.

Gentana, D., 2018. Indeks Geomorfik Sebagai Dasar Karakterisasi Neotektonik Untuk Penentuan Prospek Panas bumi di Gunung Rendingan dan Sekitarnya, Lampung. Disertasi. Fakultas Teknik Geologi Universitas Padjadjaran, Bandung.

Haryanto, I., \& Hilmi, F. 2008. 'Pola Struktur Regional Jawa Barat'. Bulletin of Scientific Contribution Geology. vol. 5, no. 1, hal. 57-66.

Haryanto, I. 2014. Evolusi Tektonik Pulau Jawa Bagian Barat Selama Kurun Waktu Kenozoikum. Disertasi. Fakultas Teknik Geologi Universitas Padjadjaran, Bandung.

Hermawan, D., \& Rezky, Y. 2011. 'Delineasi Daerah Prospek Panas Bumi Berdasarkan Analisis Kelurusan Citra Landsat di Candi Umbul - Telomoyo, Provinsi Jawa Tengah'. Buletin Sumber Daya Geologi. Vol. 6, no. 1, hal. 1-10.

Kasbani. 2009. 'Tipe Sistem Panas Bumi di Indonesia dan Estimasi Potensi Energinya'. Buletin Sumber Daya Geologi. vol. 4, no. 3, hal. 19-26.

Massinai, M.A. 2015. Geomorfologi Tektonik. Pustaka IImu. Yogyakarta. 


\section{MAKALAH ILMIAH}

Prasetio, R., Laksminingpuri, N. \& Satrio. 2018.'Karakteristik Kimia dan Isotop Fluida Panas Bumi Daerah Gunung Tampomas, Jawa Barat'. Riset Geologi dan Pertambangan. Vol. 28, no.1, hal. 1-11.

Prasetio, R., Laksminingpuri, N. \& Pujiindiyati, E.R. 2020. 'Konsentrasi Radon-222 dalam Gas Tanah untuk Deteksi Distribusi Permeabilitas di Daerah Panas Bumi Tampomas, Jawa Barat'. Eksplorium. Vol. 41, no. 1, hal. 53-60.

Sasilani, R., Haryanto, A.D., Hutabarat, J., Hermawan, D \& Widodo, S. 2019. 'Zone of Geothermal Prospects Based on Fault Fracture Density $(\mathrm{Ffd})$ Method in Sumani Region, West Sumatera'. Journal Of Geological Sciences and Applied Geology. Vol. 3, no. 2, hal. 22-35.

Siagian, R., Maryudi, M. \& Purba, V. 2018. 'Integrated Research for Geothermal Prospect Zone of Lawu Mountain Based on Geothermal Manifestation, Rock Alteration, Geochemical Analysis of Fluid, Fault Fracture Density and Magnetotelluric Data'. Proceedings of the $6^{\text {th }}$ Asian Academic Society International Conference (AASIC). Hal. 595-604.
Silitonga, P.H. 1973. Peta Geologi Lembar Bandung, Jawa. Skala 1:100.000. Bandung: Pusat Penelitian dan Pengembangan Geologi.

Suryantini, \& Wibowo, H.H,. 2010. 'Application of Fault and Fracture Density (FFD) Method for Geothermal Exploration in NonVolcanic Geothermal System; a Case Study in Sulawesi-Indonesia'. Jurnal Geoaplika. Vol. 5, no. 1, hal. $027-037$.

Thanoun, R.G. 2013. 'Automatic Extraction and Geospatial Analysis of Lineaments and their Tectonic Significance in some areas of Northern Iraq using Remote Sensing Techniques and GIS'. International Journal of Enhanced Research In Science Technology \& Engineering. Vol. 2, no. 2, hal. 1-11.

Twidale, C.R., 2004. 'River Patterns and Their Meaning'. Earth-Science Reviews. Vol. 67, no. 3-4, hal. 159218 .

$\begin{array}{ll}\text { Diterima } & : 21 \text { Juli } 2021 \\ \text { Direvisi } & : 1 \text { Agustus 2021 } \\ \text { Disetujui } & : \text { 26 Agustus 2021 }\end{array}$

